\title{
Hubungan antara konsumsi vitamin D dan gangguan depresi pada lanjut usia
}

\author{
Laksmita Dwana $^{1}$ Nugroho Abikusno ${ }^{2}$
}

\begin{abstract}
ABSTRAK
\section{LATAR BELAKANG}

Depresi merupakan salah satu penyakit yang memerlukan perhatian khusus dikarenakan penyebarannya yang sudah cukup mengglobal dan lansia merupakan penderita utamanya. Gangguan ini dapat disebabkan oleh berbagai faktor seperti riwayat kejiwaan hingga nutrisi. Berbagai penelitian menunjukkan adanya perbedaan kesehatan mental berdasarkan kecukupan konsumsi vitamin D. Oleh karenanya, dilakukan penelitian yang bertujuan untuk melihat hubungan antara konsumsi vitamin D dan gangguan depresi pada lanjut usia.
\end{abstract}

\section{METODE}

Penelitian menggunakan studi observasional dengan desain potong lintang di Panti Sosial Tresna Werda Budi Mulia 2. Data dikumpulkan dengan cara wawancara terpimpin menggunakan kuesioner yang meliputi usia, jenis kelamin, kuesioner frekuensi makanan, dan skala depresi geriatrik. Analisis data menggunakan program statistik dengan tingkat kemaknaan 0,05.

\section{HASIL}

Dari 79 responden, terdapat $82.3 \%$ berusia Young-Old, 50.6\% dengan jenis kelamin perempuan, $93.7 \%$ kurang mengkonsumsi vitamin $\mathrm{D}, 68.4 \%$ mengkonsumsi vitamin $\mathrm{D}$ di bawah rata-rata, dan 50.6\% mengalami depresi. Rata-rata konsumsi vitamin D adalah $5.05 \mathrm{mcg}$. Hubungan antara usia, jenis kelamin, konsumsi vitamin D, dan rata-rata konsumsi vitamin $\mathrm{D}$ dengan gangguan depresi memiliki nilai $\mathrm{p}>0.05$.

\section{KESIMPULAN}

Penelitian ini menujukkan tidak ada hubungan bermakna antara usia, jenis kelamin, konsumsi vitamin D, dan gangguan depresi pada lansia.
${ }^{1}$ Program Studi Kedokteran,

Fakultas Kedokteran, Universitas Trisakti

2 Departemen Ilmu Gizi, Fakultas Kedokteran, Universitas Trisakti

\section{Korespondensi:}

Nugroho Abikusno

Departemen Ilmu Gizi,

Fakultas Kedokteran,

Universitas Trisakti

Email: n_abikusno@trisakti.ac.id; nabikusno@yahoo.com

J Biomedika Kesehat 2018;1(3):179-

184

DOI: 10.18051/JBiomedKes.2018.

v1.179-184

pISSN: 2621-539X / eISSN: 2621-5470

Artikel akses terbuka (open access) ini didistribusikan di bawah lisensi Creative Commons Attribution 4.0 International (CC-BY 4.0)

Kata kunci : nutrisi, vitamin D, gangguan depresi, lanjut usia 


\section{ABSTRACT}

\section{Relationship between vitamin D consumption and depressive Disorder in The Elderly}

\section{BACKGROUND}

Depression is a disorder that requires serious attention because of its global magnitude, which greatly affects elderly. It is caused by various factors such as psychological-social history and nutrition. Recent studies show a distinction of mental health status based on the adequacy of vitamin D consumption. The study objective was conducted to distinguish the correlation between vitamin D consumption and depression in the elderly.

\section{METHODS}

Among 79 samples, $82.3 \%$ were Young-Old, 50.6\% were women, 93.7\% consumed less vitamin D, 68.4\% consumed below average vitamin D consumption, and 50.6\% were depressed. Average vitamin D consumption at Panti Sosial Tresna Werda Budi Mulia 2 was 5.05 mcg. The correlation between age, gender, vitamin D consumption, and average vitamin D consumption with depression showed $\mathrm{p}>0.05$.

\section{RESULT}

This study revealed that there was no significant correlation between age, gender, vitamin D consumption, and the average vitamin D consumption with depression in the elderly.

\section{CONCLUSION}

There is a significant relationship between waist-to-hip ratio and total blood cholesterol levels in adults.

Keywords : nutrition, vitamin D, depressive disorder, elderly

\section{PENDAHULUAN}

Depresi merupakan salah satu penyakit yang memerlukan perhatian khusus dikarenakan penyebarannya yang sudah cukup mengglobal. Pada masa kini, depresi diperkirakan sudah mempengaruhi 350 juta penduduk di dunia. Berdasarkan hasil The World Mental Health Survey yang dilaksanakan di 17 negara, ditemukan bahwa sekitar 1 dari 20 penduduk dilaporkan menderita setidaknya satu episode depresi pada tahun lalu; di mana depresi dapat mengurangi kemampuan seseorang untuk berfungsi dengan baik dan sering terjadi kekambuhan. ${ }^{(1)}$ Kejadian depresi lebih sering terjadi pula pada wanita dibandingkan pria, dengan persentase kejadian pada pria sebesar $12 \%$ dan pada wanita sebesar $20 \%$. $^{(2)}$ Seiring bertambahnya usia, penuaan tidak dapat dihindari dan terjadi beberapa perubahan fisiologis secara fisik dan mental. Selain itu, para lanjut usia mulai kehilangan pekerjaan, kehilangan tujuan hidup, kehilangan teman, risiko terkena penyakit, terisolasi dari lingkungan, dan kesepian. Hal tersebut dapat memicu terjadinya gangguan mental di mana depresi merupakan salah satu gangguan mental yang banyak dijumpai pada lanjut usia. ${ }^{(3)}$

Depresi sendiri dipengaruhi oleh berbagai faktor di antaranya adalah pengalaman bermakna di masa lalu, status sosioekonomi serta biologis, usia, jenis kelamin, serta faktor nutrisi di mana konsumsi vitamin $\mathrm{D}$ diduga berpengaruh dalam kejadian depresi. Vitamin D (calciferol) terdiri dari kelompok seco-sterol larut lemak yang ditemukan di beberapa makanan, seperti lemak ikan, jamur, kuning telur, dan hati. ${ }^{(4)}$ Beberapa percobaan klinis menunjukkan bahwa suplementasi vitamin D pada konsentrasi yang tinggi sangat direkomendasikan bagi berbagai kondisi, terutama yang dialami oleh orang lanjut usia seperti mencegah risiko terjadinya depresi, mengurangi frekuensi jatuh dan fraktur, membantu mencegah penyakit kardiovaskular, dan mengurangi gejala flu. Beberapa manfaat lainnya juga terlihat pada penderita diabetes mellitus, multiple sclerosis, Crohn's disease, nyeri, dan kemungkinan autisme. ${ }^{(5)}$

Namun, sebuah penelitian yang dilaksanakan oleh Parker G. dan Brotchie $\mathrm{H}$. pada tahun 2011 menunjukkan bahwa tidak ada hubungan yang jelas antara pengaruh konsumsi vitamin $\mathrm{D}$ terhadap timbulnya gangguan depresi pada berbagai usia.(6) Terlebih pula, penelitian eksperimental yang dilaksanakan pada tahun 2015 mengungkapkan bahwa tidak ada perbaikan depresi yang signifikan pada penderita depresi setelah pemberian vitamin $D$ secara rutin sebagai salah satu tindakan pengobatan. ${ }^{(7)}$ Dengan adanya perdebatan antara ada atau ketiadaan pengaruh dari konsumsi vitamin $\mathrm{D}$ terhadap gangguan depresi, serta mengingat pentingnya memiliki kualitas hidup yang baik melalui fungsi 
tubuh yang sehat secara jasmani dan rohani, maka diperlukan penelitian lebih lanjut untuk menelusuri hubungan antara konsumsi vitamin D dan gangguan depresi. Penelitian ini dilaksanakan dengan tujuan untuk melihat hubungan antara konsumsi vitamin D dan gangguan depresi pada lanjut usia.

\section{METODE}

Penelitian ini merupakan jenis penelitian analitik observasional dengan menggunakan metode cross-sectional. Penelitian ini mencari hubungan antara konsumsi vitamin D dan gangguan depresi pada lanjut usia di Panti Sosial Tresna Werda Budi Mulia 2, Cengkareng, Jakarta Barat yang dilakukan pada bulan OktoberNovember 2017. Sampel yang digunakan adalah laki-laki dan perempuan berusia 60 tahun atau lebih yang tinggal di lokasi penelitian. Pengambilan sampel dilakukan dengan simple random sampling untuk memilih sampel $(\mathrm{n}=79)$.

Pengumpulan data dilakukan dengan cara mengisi kuesioner melalui wawancara terpimpin. Kuesioner yang digunakan berisi informasi yang meliputi identitas (nama, usia, jenis kelamin), konsumsi vitamin $\mathrm{D}$, dan gangguan depresi.

Analisis data menggunakan program statistik untuk analisis univariat yang berupa distribusi frekuensi variabel bebas (usia, jenis kelamin, konsumsi vitamin $\mathrm{D}$, dan rata-rata konsumsi vitamin D) dan variabel tergantung (gangguan depresi), serta analisis bivariat untuk mengetahui hubungan antara konsumsi vitamin D dan gangguan depresi pada lanjut usia dengan uji statistik chi-square.

\section{HASIL}

Analisis univariat digunakan untuk mengetahui distribusi frekuensi karakteristik responden berupa usia, jenis kelamin, konsumsi vitamin $\mathrm{D}$, rata-rata konsumsi vitamin $\mathrm{D}$, dan gangguan depresi dari subjek penelitian.

Diketahui bahwa dari 79 responden lansia di Panti Sosial Tresna Budi Mulia 2 sebanyak 65 responden $(82.3 \%)$ yang tergolong kelompok usia Young-Old (60-74 tahun) dan kelompok usia Middle-Oldest-Old ( $\geq 75$ tahun) adalah sebanyak 14 responden (17.7\%). Dari 79 responden juga terdapat 39 responden $(49.4 \%)$ laki-laki dan 40 responden (50.6\%) perempuan. Berdasarkan Tabel 1 juga diketahui sebanyak 74 responden (93.7\%) kurang mengkonsumsi vitamin D dan sebanyak 5 responden $(6.3 \%)$ cukup mengkonsumsi vitamin D. Pada penilaian gangguan depresi berdasarkan skor Geriatric Depression Scale diketahui bahwa 39 responden (49.4\%) dikategorikan normal, sedangkan 40 responden $(50.6 \%)$ dikategorikan depresi.

Tabel 1. Analisis data univariat $(n=79)$

\begin{tabular}{lc}
\hline \multicolumn{1}{c}{ Distribusi Frekuensi } & n (\%) \\
\hline Usia & $65(82.3)$ \\
Young-Old (60-74 tahun) & $14(17.7)$ \\
Middle-Oldest-Old $(\geq 75$ tahun) & \\
Jenis Kelamin & $39(49.4)$ \\
Laki-laki & $40(50.6)$ \\
Perempuan & \\
Vitamin D & $74(93.7)$ \\
Kurang $(<15$ mcg) & $5(6.3)$ \\
Cukup $(\geq 15$ mcg) & \\
Rata-rata Vitamin D & $54(68.4)$ \\
Di bawah $(<5,05 \mathrm{mcg})$ & $25(31.6)$ \\
Di atas $(\geq 5,05 \mathrm{mcg})$ & \\
Gangguan Depresi & $39(49.4)$ \\
Normal $(\leq 5)$ & $40(50.6)$ \\
Depresi $(>5)$ & \\
\hline
\end{tabular}

Analisis bivariat dengan uji chi-square digunakan untuk mengetahui hubungan antara usia, jenis kelamin, rata-rata konsumsi vitamin D dan gangguan depresi pada lanjut usia. Hubungan antara konsumsi vitamin D dan gangguan depresi dianalisis menggunakan uji spearman dikarenakan tidak memenuhi syarat uji chi-square.

Diperoleh hasil pada kelompok usia Young-Old (60-74 tahun), terdapat 35 responden (53.8\%) mengalami depresi, angka ini menunjukkan bahwa kejadian gangguan depresi paling banyak terjadi pada usia di bawah 75 tahun. Pada kelompok usia Middle-Oldest-Old ( $\geq 75$ tahun), terdapat 9 responden $(64.3 \%)$ memiliki angka kesehatan mental tertinggi. Hasil uji statistik chi-square diperoleh nilai probabilitas $\mathrm{p}=0.218$ dimana angka tersebut lebih besar dari nilai $\alpha=0.05$, sehingga dapat disimpulkan bahwa tidak ada hubungan bermakna antara usia dan gangguan depresi.

Diperoleh hasil pada kelompok jenis kelamin laki-laki, terdapat 23 responden (59\%) mengalami depresi, angka ini menunjukkan bahwa 
kejadian gangguan depresi lebih banyak terjadi pada laki-laki dibandingkan pada perempuan. Pada kelompok jenis kelamin perempuan, terdapat 23 responden (57.5\%) memiliki kesehatan mental yang normal dibandingkan dengan laki-laki. Hal ini menunjukkan bahwa perempuan memiliki kesehatan mental yang lebih baik (normal) dibandingkan dengan kelompok jenis kelamin laki-laki. Hasil uji statistik chi-square diperoleh nilai probabilitas $\mathrm{p}=0.143$ dimana angka tersebut lebih besar dari nilai $\alpha=0.05$, sehingga dapat disimpulkan bahwa tidak ada hubungan bermakna antara jenis kelamin dan gangguan depresi.

Diperoleh hasil pada kelompok responden yang kurang mengkonsumsi vitamin $\mathrm{D}$, terdapat 38 responden (51.4\%) memiliki kesehatan mental yang normal, sedangkan terdapat sebanyak 4 responden $(80 \%)$ mengalami gangguan depresi pada kelompok yang cukup mengkonsumsi vitamin D. Hasil uji statistik spearman diperoleh nilai probabilitas $\mathrm{p}=0.153$ dimana angka tersebut lebih besar dari nilai $\alpha=0.05$, sehingga dapat disimpulkan bahwa tidak ada hubungan bermakna antara jenis kelamin dan gangguan depresi.

Dikarenakan data konsumsi vitamin D memiliki perbedaan yang cukup signifikan, maka peneliti menggunakan rata-rata vitamin $D$ yang dikonsumsi oleh responden penelitian di Panti Sosial Tresna Werda Budi Mulia 2 sebagai variabel bebas untuk diuji kembali.

Analisis bivariat dengan uji chi-square digunakan untuk mengetahui hubungan antara rata- rata konsumsi vitamin $\mathrm{D}$ dan gangguan depresi pada lanjut usia. Nilai rata-rata konsumsi vitamin D lanjut usia di Panti Sosial Tresna Werda Budi Mulia 2 adalah 5.05 mcg yang ditentukan dengan memasukan rumus average di program Microsoft Excel dan menghitung rata-rata berdasarkan hasil ukur vitamin D menggunakan nutrisurvey.

Diperoleh hasil pada kelompok responden yang mengkonsumsi vitamin $\mathrm{D}$ di bawah ratarata, terdapat 28 responden $(51.9 \%)$ tidak mengalami depresi. Pada kelompok responden yang mengkonsumsi vitamin $\mathrm{D}$ di atas rata-rata, terdapat 14 responden (56\%) memiliki gangguan depresi. Hal ini menunjukkan bahwa gangguan depresi lebih banyak terjadi pada responden yang mengkonsumsi vitamin D di atas rata-rata. Hasil uji statistik chi-square diperoleh nilai probabilitas $\mathrm{p}=0.516$ dimana angka tersebut lebih besar dari nilai $\alpha=0.05$, sehingga dapat disimpulkan bahwa tidak ada hubungan bermakna antara jenis kelamin dan gangguan depresi.

\section{PEMBAHASAN}

Diperoleh hasil yang menunjukkan bahwa tidak ada hubungan bermakna antara kedua variabel tersebut. Menurut Wiesel TRW, et al, kedua variabel ini tidak memiliki hubungan antara satu sama lain dikarenakan usia bukan merupakan faktor risiko terjadinya gangguan depresi. Gangguan depresi pada lanjut usia sendiri disebabkan oleh adanya riwayat psikososial yang mendalam atau adanya penyakit kronis yang diderita, serta minimnya dukungan sosial

Tabel 2. Analisis data bivariat

\begin{tabular}{|c|c|c|c|}
\hline & \multicolumn{2}{|c|}{ Gangguan Depresi } & \multirow[b]{2}{*}{ p value } \\
\hline & $\begin{array}{l}\text { Normal } \\
\text { n (\%) }\end{array}$ & $\begin{array}{r}\text { Depresi } \\
\text { n (\%) }\end{array}$ & \\
\hline Usia & & & \multirow{3}{*}{$0.218^{\epsilon}$} \\
\hline Young-Old (60-74 tahun) & $30(46.2)$ & $35(53.8)$ & \\
\hline Middle-Oldest-Old ( $\geq 75$ tahun) & $9(64.3)$ & $5(35.7)$ & \\
\hline Jenis Kelamin & & & \\
\hline Laki-laki & $16(41)$ & $23(59)$ & \multirow{2}{*}{$0.143^{€}$} \\
\hline Perempuan & $23(57.5)$ & $17(42.5)$ & \\
\hline Vitamin D & & & \multirow{3}{*}{$0.153^{¥}$} \\
\hline Kurang & $38(51.4)$ & $36(48.6)$ & \\
\hline Cukup & $1(20)$ & $4(80)$ & \\
\hline Rata-rata Vitamin D & & & \multirow{3}{*}{$0.516^{€}$} \\
\hline Di bawah & $28(51.9)$ & $26(48.1)$ & \\
\hline Di atas & $11(44)$ & $14(56)$ & \\
\hline
\end{tabular}

$\mathrm{n}=$ jumlah; $\%=$ persentase; $€=$ uji Chi-Square; $¥=$ uji Spearman 
yang merupakan pemeran utama dari terjadinya gangguan depresi. ${ }^{(8)}$ Namun, dapat dilihat dengan jelas bahwa kejadian gangguan depresi paling banyak ditemukan pada kelompok lansia Young-Old (60-74 tahun). Berdasarkan penelitian mengenai active ageing yang dilakukan oleh European Commision, individu yang baru mengalami transisi dari dewasa akhir menuju lanjut usia (lansia) awal memiliki tendensi mengalami depresi lebih tinggi dikarenakan oleh beberapa faktor seperti penurunan kemampuan berkegiatan sehari-hari dan usainya masa kerja, serta waktu senggang yang cukup banyak menyebabkan rasa bosan yang mendalam. Untuk mengatasi hal tersebut, dukungan dari keluarga dan lingkungan sekitar merupakan tatalaksana primer. ${ }^{(9)}$ Hal yang serupa juga ditemukan pada penelitian Barua A, et al yang menunjukkan tingkat depresi tertinggi ditemukan pada kelompok lansia muda (YoungOld Elderly) dan usia 68 tahun adalah usia yang paling sering mengalami gangguan depresi. (10)

Diperoleh hasil yang menunjukkan tidak ada hubungan bermakna antara kedua variabel tersebut. Hasil ini juga dijelaskan pada penelitian oleh Girgus JS, et al yang menyatakan bahwa kedua jenis kelamin dapat mengalami gangguan depresi dengan tingkat yang serupa. Penyebab utama gangguan depresi adalah kejadian buruk di kehidupan atau adanya stresor. Laki-laki dapat mengalami kejadian buruk berupa masa perang, sedangkan wanita mengalami stressor berupa kekerasan. Hal ini menjelaskan bahwa jenis kelamin bukan salah satu penyebab atau faktor risiko dari terjadinya gangguan depresi, sehingga tidak dapat ditemukan adanya hubungan bermakna antara kedua variabel. Lakilaki dan perempuan juga menunjukkan tanda gangguan depresi yang berbeda, dimana laki-laki akan bersikap lebih agresif dan perempuan lebih diam. ${ }^{(11)}$ Namun, dapat dilihat bahwa gangguan depresi lebih banyak terjadi pada lansia berjenis kelamin laki-laki daripada perempuan. Hasil ini didukung pula oleh penelitian yang melibatkan 487.275 lansia dengan gangguan depresi terdapat $64 \%$ di antaranya adalah laki-laki dikarenakan kehilangan kesibukan sehari-hari, belum bisa menerima kondisi fisik yang menurun akibat penuaan, dan mempunyai tendensi untuk menyimpan perasaannya sendiri. ${ }^{(10)}$
Diperoleh hasil yang menunjukan tidak ada hubungan bermakna antara konsumsi vitamin D dan gangguan depresi pada lansia. Hal ini disebabkan oleh faktor sampel yang tidak mewakili populasi dikarenakan hanya terdapat lima responden yang tergolong cukup mengkonsumsi vitamin D. Beberapa hal yang diduga sebagai penyebab kejadian ini adalah menu makanan yang disediakan sehari-hari bersifat homogen dan rendah vitamin D (rendang sapi, telur balado, susu, dan ikan sarden), riwayat penyakit yang diderita, serta minimnya kegiatan yang menempatkan lansia berada di bawah paparan sinar matahari. Lansia yang tinggal di panti sosial memang mendapat asupan beberapa mikronutrien yang kurang. Penelitian yang dilaksanakan di Pantri Tresna Werda Bogor dan Panti Tresna Hanna Bogor menyatakan bahwa rata-rata konsumsi kalsium yang berkaitan dengan vitamin D pada lansia di lokasi tersebut berada dalam kategori kurang $74.4 \%$, sedangkan angka kecukupannya adalah $75 \%$. Hal ini disebabkan oleh keterbatasan menu makanan yang disediakan dan juga tergantung dari selera lansia itu sendiri. ${ }^{(12)}$

Dengan ini, hasil data penelitian diuji kembali dengan mengukur rata-rata konsumsi vitamin D pada lansia di Panti Sosial Tresna Werda Budi Mulia 2 sebagai variabel bebas dan gangguan depresi sebagai variabel tergantung. Hasil uji statistik menunjukkan bahwa tidak ada hubungan bermakna antara rata-rata konsumsi vitamin D dan gangguan depresi. Hasil ini didukung pula dari penelitian yang dilaksanakan oleh Veleva BI, et al yang menyatakan bahwa pemberian suplementasi vitamin D dengan dosis 5600 IU satu kali setiap minggu menunjukkan tidak ada perbaikan gangguan depresi. (13) Masih terlalu dini untuk menegakkan bukti adanya hubungan antara konsumsi vitamin D dan gangguan depresi dikarenakan psikopatologi depresi yang tidak mempunyai hubungan langsung dengan vitamin D. Belum ada studi yang menjelaskan mekanisme pengaruh langsung vitamin D terhadap monoamin dan/atau fungsi HPA axis, maupun peran vitamin D terhadap neurogenesis hipokampus. ${ }^{(14)}$

Keterbatasan yang terdapat pada penelitian ini adalah menu makanan yang tersedia bersifat homogen dan kuantitas yang dikonsumsi 
tergolong sedikit, sehingga kadar vitamin D didapat rendah; serta senam lansia atau kegiatan yang memerlukan paparan sinar matahari kurang rutin, sehingga aktivasi progenitor vitamin $\mathrm{D}$ tidak terjadi. Hal tersebut menjadi salah satu faktor kadar vitamin D yang terdapat rendah.

\section{KESIMPULAN}

Berdasarkan hasil penelitian dan pembahasan, maka dapat disimpulkan mengenai penelitian hubungan antara konsumsi vitamin D dan gangguan depresi pada lanjut usia di Panti Sosial Tresna Werda Budi Mulia 2 adalah tidak ada hubungan bermakna antara usia dan gangguan depresi, tidak ada hubungan bermakna antara jenis kelamin dan gangguan depresi, tidak ada hubungan bermakna antara konsumsi vitamin $\mathrm{D}$ dan gangguan depresi, nilai rata-rata vitamin D yang dikonsumsi oleh lansia di Panti Tresna Werda Budi Mulia 2 adalah $5.05 \mathrm{mcg}$, serta tidak ada hubungan antara rata- rata konsumsi vitamin D dan gangguan depresi pada lanjut usia dan Panti Sosial Tresna Werdha Budi Mulia 2, Cengkareng, Jakarta Barat.

Peneliti menyadari masih terdapat kekurangan dalam melakukan penelitian ini, tidak semua faktor diteliti dikarenakan keterbatasan waktu dan tenaga. Oleh karena itu, sangat diharapkan ada peneliti lain yang berminat melanjutkan penelitian ini dan membuat penelitian lanjutan dengan mengkritisi beberapa hal. Untuk menyempurnakan penelitian tentang hubungan antara konsumsi vitamin D dan gangguan depresi pada lanjut usia, maka studi selanjutnya dapat memperhatikan beberapa hal lebih dalam lagi, seperti:

1. Lokasi penelitian yang digunakan sebaiknya meliputi berbagai macam lapisan agar memperluas karakteristik sampel penelitian, seperti jenis makanan yang bervariasi dan aktivitas fisik yang terpapar oleh sinar matahari.

2. Serum vitamin D dengan dosis tinggi dapat digunakan sebagai variabel bebas.

3. Teknis pelaksanaan wawancara terpimpin untuk memeriksa gangguan depresi dapat disesuaikan dengan standar operasional prosedur wawancara psikiatri.

\section{DAFTAR REFERENSI}

1. World Health Organization. Depression: A Global Public Health Concern. Geneve: World Health Organization; 2012.

2. Belmaker RH, Agam G. Major Depressive Disorder. N Engl J Med. 2008; 358(1): 55-68. DOI: 10.1056/NEJMra073096

3. Irawan H. Gangguan Depresi pada Lanjut Usia. Cermin Dunia Kedokteran. 2013; 40(11):815-9

4. Holick MF. Vitamin D defciency. N Engl J Med. 2007;357:266-81. DOI: 10.1056/NEJMra070553

5. Kauffman JM. Benefits of Vitamin D Supplementation. Journal of American Physicians and Surgeons 2009; 14 (2):38-44

6. Parker G, Brotchie H. 'D' for Depression: Any Role for Vitamin D? 'Food for Thought' II. Acta Psychiatr Scand. 2011;124(4):243-9. doi: 10.1111/ j.1600-0447.2011.01705.

7. Gowda U, Mutowo MP, Smith BJ, Wluka AE, Renzaho AM. Vitamin D Supplementation to Reduce Depression in Adults: Meta-Analysis of Randomized Controlled Trials. Nutrition. 2015;31(3):421-9. doi: 10.1016/j.nut.2014.06.017.

8. Wiesel TRW, Nelson CJ, Twe WP, Hardt M, Mohile SG, Owusu C, et al. The Relationship Between Age, Anxiety, and Depression in Older Adults With Cancer. Psychooncology. 2015; 24(6):712-7. doi: 10.1002/pon.3638.

9. European Commission. Active Aging. Available at http://ec.europa.eu/commfrontoffice/ publicopinion/archives/ebs/ebs 378 en.pdf.

Accessed on December 12, $201 \overline{7}$.

10. Barua A, Ghosh MK, Kar N, Basilio MA. Prevalence of Depressive Disorders in The Elderly. Ann Saudi Med. 2011; 31(6):620-4. doi: 10.4103/0256-4947.87100.

11. Girgus JS, Yang K, Ferri CV. The Gender Difference in Depression: Are Elderly Women at Greater Risko for Depression Than Elderly Men? Geriatrics. 2017;2(35):5-6. doi:10.3390/ geriatrics2040035

12. Marjan AQ dan Marliyati SA. Hubungan antara Pola Konsumsi Pangan dan Aktivitas Fisik dengan Kejadian Osteoporosis pada Lansia di Panti Werdha Bogor. Jurnal Gizi dan Pangan. 2013; 8(2): 123-8. DOI: http://dx.doi.org/10.25182/ jgp.2013.8.2.123-128

13. Veleva BI, Chel VG, Achterberg WP. Efficacy of Daily 800 IU Vitamin D Supplementation in Reaching Vitamin D Suffeciency in Nursing Home Residents: Cross-Sectional Patient File Study. BMC Geriatr. 2014;14:103. doi: 10.1186/1471-2318-14-103.

14. Bertone-Johnson ER. Vitamin D and The Occurrence of Depression: Causal Association or Curcumstantial Evidence? Nutr Rev. 2009; 67(8): 481-92. doi: 10.1111/j.1753-4887.2009.00220.x 